\title{
Analysis of the Mechanical Properties of Concrete Mix Added with Water Lily Ash (Eichornnia Crassipes)
}

\author{
J. Ignacio Anchondo-Perez, E. Jonathan Suarez-Dominguez, J. Francisco Perez-Sanchez \\ M. Arturo Varela-Tovar
}

Faculty of Architecture, Design and Urbanism, The Autonomous University of Tamaulipas, Circuito Interior S/N, Tampico, Tamaulipas, Mexico

Received May 6, 2021; Revised June 7, 2021; Accepted July 19, 2021

\begin{abstract}
Cite This Paper in the following Citation Styles
(a): [1] J. Ignacio Anchondo-Perez, E. Jonathan Suarez-Dominguez, J. Francisco Perez-Sanchez, M. Arturo Varela-Tovar, "Analysis of the Mechanical Properties of Concrete Mix Added with Water Lily Ash (Eichornnia Crassipes)," Civil Engineering and Architecture, Vol. 9, No. 5, pp. 1389 - 1394, 2021. DOI: 10.13189/cea.2021.090512.
\end{abstract}

(b): J. Ignacio Anchondo-Perez, E. Jonathan Suarez-Dominguez, J. Francisco Perez-Sanchez, M. Arturo Varela-Tovar (2021). Analysis of the Mechanical Properties of Concrete Mix Added with Water Lily Ash (Eichornnia Crassipes). Civil Engineering and Architecture, 9(5), 1389 - 1394. DOI: 10.13189/cea.2021.090512.

Copyright $\odot 2021$ by authors, all rights reserved. Authors agree that this article remains permanently open access under the terms of the Creative Commons Attribution License 4.0 International License

\begin{abstract}
The pollution associated with construction materials production has led to searching for new or existing sustainable and efficient replacements. Some materials are not directly defined as construction materials, but they have properties applied in the field. The pursuit of sustainable materials to be used in the construction industry has been focused on organic materials such as extracts or fibers directly used in concrete mixtures and other construction elements like CEB (Compressed Earth Blocks). In this work, water lily ash (Eichornnia Crassipes) from Tamaulipas southern is proposed to replace cement in concrete mixtures and evaluate its effect on mechanical, thermal, and sound diffusion properties. The consumption of lily ash controls its exponential growth in aquatic environments and is presented as a solution to the adverse effects on aquatic flora and fauna developed by this invasive species. The water lily specimens were taken from the southern Tamaulipas and calcinated in a ground furnace to take advantage of traditional regional techniques with low energy consumption, obtaining $2,45 \mathrm{~kg}$ of ashes from approximately $18 \mathrm{~kg}$ of raw material $(13,6 \%$ yield). Concrete mixtures were obtained with Portland cement, water, coarse gravel $\left(19 \mathrm{~mm}, 2.7 \mathrm{ton} / \mathrm{m}^{3}\right)$, and local river sand for 15,$2 ; 8,8 ; 42,2$; and $33,8 \% \mathrm{w} / \mathrm{w}$, respectively. Lily ashes were dosed as cement replacement for 0,$5 ; 1,2$, and $3 \% \mathrm{w} / \mathrm{w}$. It was found that $1 \%$ of ashes substituting cement equals the compressive strength and reduces the thermal transmissive by $12.53 \%$. Besides, sound diffusion velocity
\end{abstract}

is increased, which indicates that ash promotes a better particle distribution without compromising mechanical properties. Therefore, lily ash is a good candidate as a cement substituent, and it would be double troubleshooting: reduction of cement consumption and elimination of lily ash as invasive species.

Keywords Lily Ash Particles, Improvement of Cement Properties, Sustainable Construction Material

\section{Introduction}

The worldwide construction industry is mainly based on concrete elements [1]. The environmental impact that cement production generates is well known, and nowadays, its mitigation has been pursued through eco-friendly materials. The cement manufacturing industry is under scrutiny due to the large volumes of $\mathrm{CO}_{2}$ emitted. In reality, it is estimated that it represents more than $10 \%$ of the total anthropogenic $\mathrm{CO}_{2}$ emissions. Other cement emissions, such as $\mathrm{SO}_{2}$ emissions, have also been analyzed using the Life Cycle Assessment (LCA) method. This method refers to the international standard ISO 14040 and has been applied to the construction industry since 1990. The inclusion of each stage of the process or product life cycle is essential for this analysis. However, in some cases, a complete life cycle analysis (cradle to grave) is not relevant, and the analysis must end at an 
intermediate stage (cradle to door). When cement production is analyzed, it is here, which has multiple specific applications in civil works (like beams, pillars, pavements, or bridges) and therefore does not allow defining a single life cycle. However, any partial analysis is helpful to construct complete life cycles for specific cement end products (like beams, columns, or pavements). Therefore, reliable results on the impacts of cement production are needed for larger-scale studies, which deal with concrete (material scale) up to structure design (infrastructure scale). [2].

Recycled concrete is increasing interest for use as aggregate in structural concrete, and several types of research have examined its performance. Natural fibers and demolition wastes have been used to improve the mechanical properties of concrete mixtures [3-5]. However, the integrity of organic matter is compromised by the final use of the construction material $[6,7]$. Some investigations have been conducted to determine the effect of nopal mucilage or aloe vera in stabilizing concrete mixtures. Some others have studied the effect of ixtle or coconut fibers in enhancing the mechanical properties of concrete samples. However, these natural materials added to the mixtures come from plants produced as food or are considered organic wastes used in composting processes. Thus, such works are not focused on natural materials that are invasive species, as is aquatic lily.

The aquatic lily (Eichhornia crassipes), also known as swamp, water flower, lettuce, Jacinto, or nymph, is considered one of the roughest aquatic weeds worldwide, causing severe impact on ecosystems biodiversity [8-11]. Some works [8-11] have proposed alternatives such as composting or vermicomposting to consume water lily and mitigate the negative consequences of its interaction with the media. Based on the use of some organic ash materials [12-14], this work aims to use ashes of water lily obtained from the south of Tamaulipas, Mexico, as cement replacement in concrete mixtures. The parameters analyzed in contrast to regular concrete were mechanical properties, heat transfer, and sound diffusion.

\section{Materials and Methods}

The aquatic lily was sampled, cataloged, and classified. The characterization consisted of the wet volumetric weight, tingling volumetric weight, the volumetric weight of the plant dehydrated in a furnace, and the volumetric weight of the ash.

\subsection{Collection, characterization, and calcination of water lily}

The lily was collected manually on the Champayan lagoon in Altamira, Tamaulipas, Mexico (22 22 '33.0 "N $\left.97^{\circ} 59^{\prime} 05.2^{\prime \prime} \mathrm{W}\right)$. Specimens were selected of the same size and characteristics to ensure homogeneity. The water lily (Eichhornia crassipes) is a floating aquatic plant native to Brazil.

Regarding its morphology, the water lily has a very striking appearance. Its size is variable, but it measures around $30 \mathrm{~cm}$ in length. It has a reduced stem and an elongated rhizome that connects several individuals. The leaves are found forming a basal rosette. In plants attached to the substrate, the petioles are long and cylindrical, and in floating plants, short and globose. The leaf blades are almost circular and broader than long $(3,5$ to $16 \mathrm{~cm}$ long and 3 to $12 \mathrm{~cm}$ wide). They have a truncated and rounded apex. Figure 1 shows a representative specimen of water lily collected.

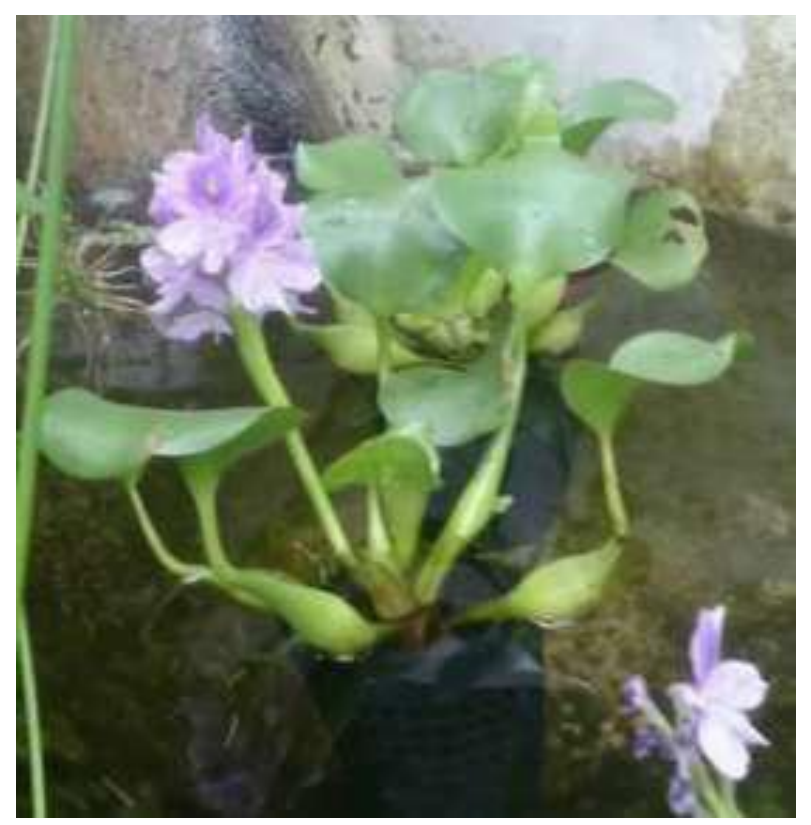

Figure 1. Specimen of water lily (Eichhornia crassipes) collected in Altamira, Mexico.

Figure 2 shows the selected area for the collection of specimens. It was found that local fishers move the plants to areas where they can take them out in an easy way, and this is the solution implemented by the local people to remove the invasive plants from the lagoon and avoid the reduction of fauna, increasing their production for selling. 

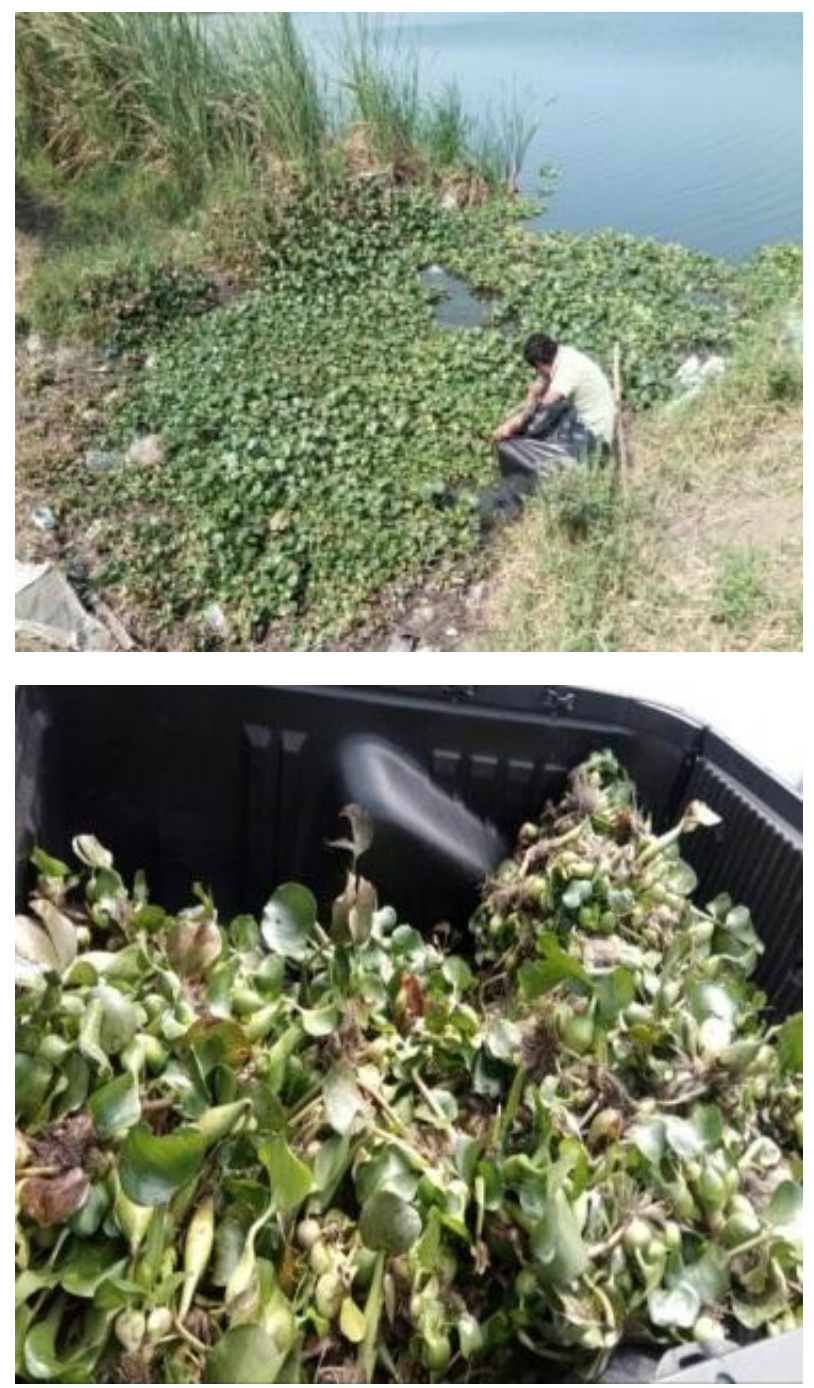

Figure 2. Collection and transport of water lily (Eichhornia crassipes).

Solar dehydration was employed as the drying process, allowing the water content to evaporate after approximately four months from harvesting.

The volumetric weight (VW) was determined by weighing a selected specimen before and after dry in an oven. After the drying process, samples were set at a constant weight to determine the total water content $(\% \mathrm{w} / \mathrm{w})$. The dried material was placed in a calcination ground pit for obtaining ashes. This method allows obtaining ashes without energy consumption.

\subsection{Concrete Mixtures}

The concrete mixture was produced according to the ACI 211.1 method for the design of concrete mixtures applying the proportions shown in Table 1 .
Table 1. Proportions by weight of the concrete mixture

\begin{tabular}{|c|c|}
\hline Material & \% w/w \\
\hline Portland cement & 15.2 \\
\hline Water & 8.8 \\
\hline Coarse gravel $\left(19 \mathrm{~mm} \mathrm{VW}=2.7 \mathrm{ton} / \mathrm{m}^{3}\right)$ & 42.2 \\
\hline Local river sand & 33.8 \\
\hline
\end{tabular}

Cement content was partially substitued in the mixture in four levels:

$$
\begin{aligned}
& 14.7 \text { cement }+0.5 \% \text { ash } \\
& 14.2 \text { cement }+1 \% \text { ash } \\
& 13.2 \text { cement }+2 \% \text { ash } \\
& 12.2 \text { cement }+3 \% \text { ash }
\end{aligned}
$$

Gravel was obtained from Grava del Abra, Co., and cement was purchased from CEMEX. The mixture was made in a controlled space to avoid contamination from dust or other fine particles. For all tests, 5 cylindrical specimens were produced with 10x20 cm (diameter/height). River sand was collected in the zone under study.

Specimens were immersed in water to maintain the perfect hydration of the concrete for 28 days, and then compression tests were performed under ASTM C39 and C617 with a Controls Universal Machine.

\subsection{Ultrasonic Pulse Test and Thermal Analysis}

The pulse test consists of measuring the time it takes for an ultrasonic pulse (frequency between 20 and 150 $\mathrm{kHz}$ ) to travel the distance between a $\mathrm{Tx}$ emitting transducer and an $\mathrm{Rx}$ receiver transducer coupled to the concrete under study. In this case, a UPV-E48 Ultrasonic Pulse Velocity Tester from Controls was employed to determine the velocity sound travel in $\mathrm{m} / \mathrm{s}$. For thermal analysis, a portable differential scanning calorimeter was used, complying with ASTM E1269 standard.

\section{Results and Discussion}

The results of lily obtained from Tamaulipas southern were $14.34 \%$ in dry weight. The ash resulting from the calcination of the lily was $2,45 \mathrm{~kg}$ obtained from around 100 plants collected (Figure 3). The approximate weight of the humid specimens was $18 \mathrm{~kg}$, and the ash quantity obtained represents a $13,6 \%$ yield. The ash from the aquatic lily is as follows: black powder, fine consistency, easy handling, and high homogeneity. 


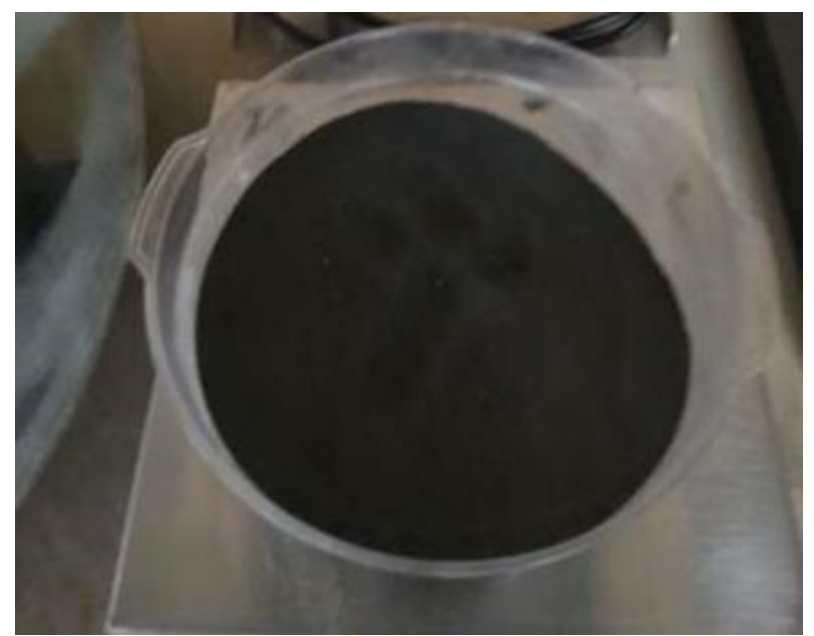

Figure 3. Lily ash obtained after calcination of dry material.

The granulometry of ash and sand is presented in Table 2 , with the particle percentage passing through different meshes.

Table 2. Granulometry of ash and river sand (\% w/w)

\begin{tabular}{|c|c|c|}
\hline Mesh & Lily-ash & River Sand \\
\hline $3 / 4$ & - & 100 \\
\hline 4 & - & 99 \\
\hline 8 & - & 97 \\
\hline 10 & 100 & 93 \\
\hline 20 & 100 & 66 \\
\hline 40 & 79 & 15 \\
\hline 50 & 62 & 10 \\
\hline 60 & 57 & 8 \\
\hline 100 & 24 & - \\
\hline 200 & 10 & - \\
\hline $\mathrm{P}-200$ & 0 & - \\
\hline Density $\left(\mathrm{kg} / \mathrm{m}^{3}\right)$ & 2.408 & 2.501 \\
\hline
\end{tabular}

Compression results are shown in Figure 3. It is observed that the substitution of cement by lily ash diminishes the compressive strength. However, it was found that $1 \%$ of ashes replicates the strength of original concrete.

Table 3. Result of compressive strength

\begin{tabular}{|c|c|}
\hline Sample & $\begin{array}{c}\text { Compressive strength } \\
\left(\mathbf{k g} / \mathbf{c m}^{\mathbf{2}}\right)\end{array}$ \\
\hline Concrete & $85,5 \pm 2,5$ \\
\hline $0,5 \%$ ash & $62,5 \pm 1,3$ \\
\hline $1,0 \%$ ash & $84,0 \pm 2,1$ \\
\hline $2,0 \%$ ash & $58,9 \pm 4,7$ \\
\hline $3,0 \%$ ash & $47,5 \pm 5,9$ \\
\hline
\end{tabular}

Ultrasonic pulse results are shown in Table 4. A significant increase of pulse velocity for the $1 \%$ dosage is observed, which can be related to better particle contact and distribution in the sine of the solid.
Table 4. Results for Ultrasonic speed test

\begin{tabular}{|c|c|}
\hline Sample & Speed $\mathbf{~ m} / \mathbf{s}$ \\
\hline Concrete & 353,7 \\
\hline $0,5 \%$ ash & 349,8 \\
\hline $1,0 \%$ ash & 396,2 \\
\hline $2,0 \%$ ash & 358,2 \\
\hline $3,0 \%$ ash & 329,6 \\
\hline
\end{tabular}

Additionally, the water absorption behavior was analyzed. After 24 hours of water immersion, the weight/volume ratio was measured and is presented in Table 5.

Table 5. Results of weight/volume ratio after $24 \mathrm{~h}$ of water immersion

\begin{tabular}{|c|c|}
\hline Sample & $\begin{array}{c}\text { Weight/Volume ratio } \\
\left(\mathbf{k g} / \mathbf{m}^{\mathbf{3}}\right)\end{array}$ \\
\hline Concrete & 8,6 \\
\hline $0,5 \%$ ash & 10,2 \\
\hline $1,0 \%$ ash & 8,4 \\
\hline $2,0 \%$ ash & 9,8 \\
\hline $3,0 \%$ ash & 10,9 \\
\hline
\end{tabular}

It can be observed that $1 \%$ ash addition allows replicating the water absorption as a regular concrete mixture, which indicates that this is the dosage level that promotes a better pore filling effect in combination with cement.

The thermal analysis describes the thermal transmission of the mixtures. The result obtained for original concrete was $1.508 \mathrm{~W} / \mathrm{mK}$, but for $0,5,1,2$, and $3 \%$ of cement substitution, the value was decreased to $1.453,1.385$, 1.352 , and 1.319 , respectively. A linear correlation (Figure 4) observed between ash content and heat transfer indicates that ash promotes a diffusion effect as it is observed a lower thermal transmissive for higher ash content.

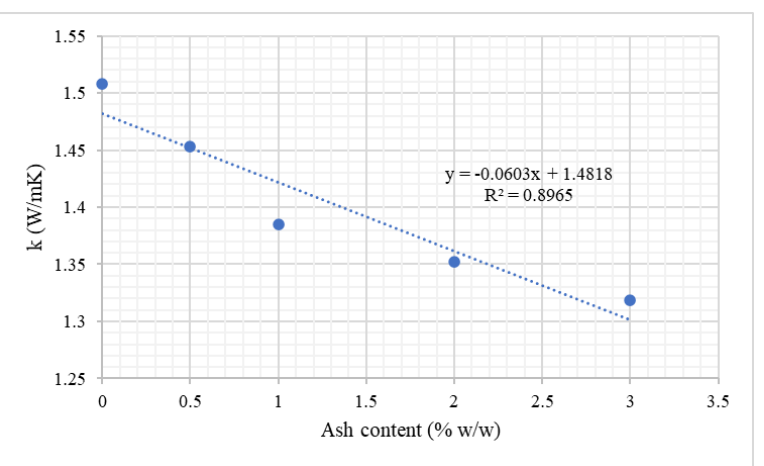

Figure 4. Thermal conductivity $(\mathrm{W} / \mathrm{mK})$ for the mixtures of concrete and added with lily ash.

Surface analysis was developed to study the contribution of lily ash from a fractal perspective. Pictures of the samples were taken with a digital microscope. This 
study only considered the mixture of regular concrete and the mixture with $1 \%$ of lily ash. The images shown in Figure 5 were transformed to the binary format, and through the software ImageJ, the box count method was employed to obtain the fractal dimension. The fractal dimension values were 1.6346 for concrete mixture and 1.7858 for $1 \%$ lily ash dosage with a standard deviation of 0.0018 in both cases [15].

The fractal dimension values were used to obtain the spatial projection of the solids in 3D format, as shown in Figure 6 [16]. It can be observed a higher homogeneity when the lily ash is present in the mixture. In this sense, a relation between lily ash content and the physical and mechanical properties observed in this work is established. Thus, it can be concluded that there is sufficient evidence in the records of the tests carried out that the behavior of concrete with $1 \%$ water lily ash. Results in terms of mechanical resistance to compression without significant differences compared with standard concrete mixture, but there is variation in the mechanical characteristics regarding the increase to $3 \%$ of the water lily ash. It can be observed that although the compressive strength decreases, other properties are enhanced.
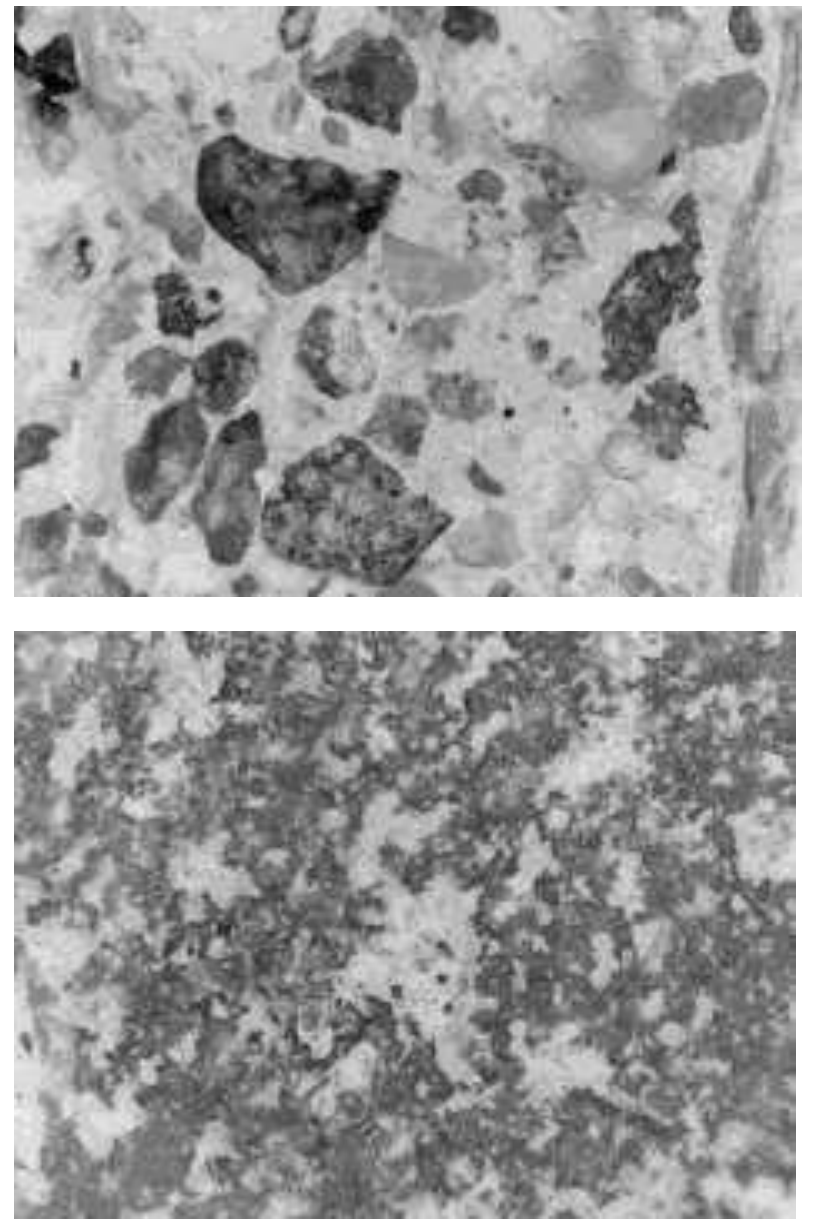

Figure 5. Photographies of the surface of the standard concrete sample (up) and mixture dosed with $1 \%$ of lily ash (down).
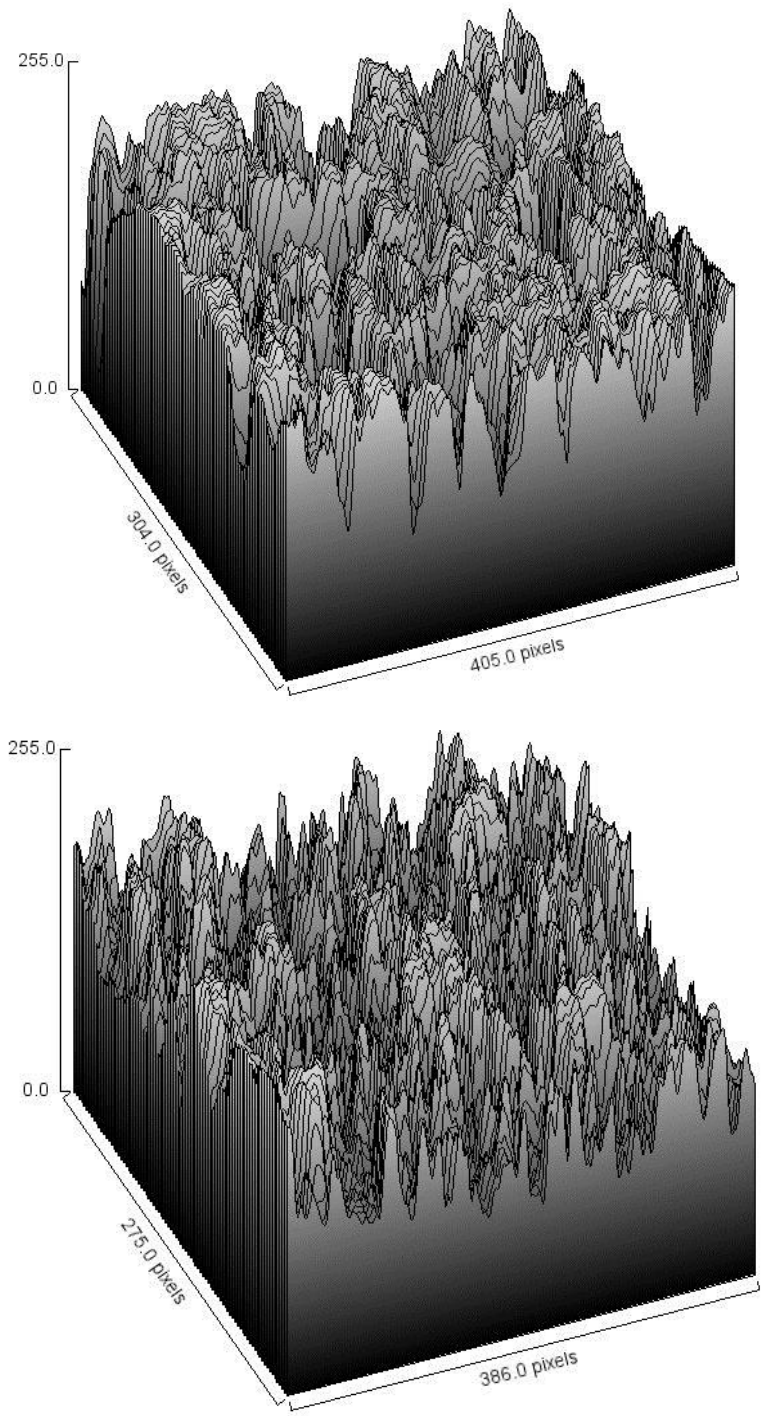

Figure 6. 3D spacial projection of the standard concrete sample (up) and mixture dosed with $1 \%$ lily ash (down).

\section{Conclusions}

Water lily (Eichornnia Crassipes) is a widespread species in the vessels of southern Tamaulipas and is one of the most harmful species for ecosystems due to its growth restricts oxygen consumption and sunlight in an aquatic environment. This work aims with the consumption of lily to obtain ash as cement replacement in concrete mixtures. It was found that $1 \%$ of ash matches the compressive strength of a regular concrete mixture. This result corresponds to the observed behavior of thermal transmissive and sound diffusion. Thermal transmissive is reduced for ash dosed, and the sound velocity diffusion is increased, which indicates that ashes promote a better dispersion of particles. Therefore, thermal comfort can be achieved as the reduction of cement consumption is established.

However, as the calcination process produces $\mathrm{CO} 2$, 
further work must analyze ecological techniques for calcination, and a carbon print analysis must be developed.

\section{Acknowledgments}

The authors thank the PRODEP program for its support.

\section{REFERENCES}

[1] Vásquez, B., \& Corrales, S. Industria del cemento en México: análisis de sus determinantes. Problemas del desarrollo, 48(188), pp. 113-138. 2017

[2] Güereca, L. P. Evaluación comparativa de los impactos ambientales de la producción de clínker con combustible fósil frente a combustible derivado de los residuos. Gaceta Instituto de Ingeniería, UNAM, 1(86), pp. 16-19. 2017

[3] Ballesteros, J. E. M., Junior, H. S., Fiorelli, J., \& Frías, M. Prestaciones de las fibras vegetales en la producción de composites de cementos reforzados. Cemento Hormigón, (981), pp. 26-34. 2017

[4] Frías, M., Sánchez de Rojas, M. I., Asensio, E., \& Medina, C. Valorización de los residuos de construcción y demolición (RCD) como puzolanas alternativas en la fabricación de cementos eco-eficientes. Valorización de los residuos de construcción y demolición (RCD) como puzolanas alternativas en la fabricación de cementos eco-eficientes, pp. 1-62. 2018.

[5] Martínez-Martínez, S., Eliche-Quesada, D., Pérez-Villarejo, L., Angelopoulos, G. N., \& Sánchez-Soto, P. J. Valorización de chamota residual derivada de la producción de ladrillos de construcción cerámicos para el desarrollo de un nuevo tipo de clínker de cemento belítico. 2016. Available at: http://www. conama11. vsf. es/conama10/download/files/conama2016/CT, 202016(1), 998971922.

[6] Izquierdo, I., Soto Izquierdo, O., \& Ramalho, M. Propiedades físicas y mecánicas del hormigón usando polvo residual de desechos orgánicos como reemplazo parcial del cemento. Revista ingeniería de construcción, 33(3), pp. 229-240. 2018.

[7] Velázquez, L. C., García, H. L. C., Chiquito, M. C. G., Guzmán, E. A. N., \& Leal, O. S. M. Evaluación de la durabilidad del empedrado de pueblos mágicos con adiciones orgánicas en morteros base cemento. In Congreso CONPAT 2019, Tuxtla Gutiérrez, Chiapas. 2019, September

[8] Moore, B. C., Funk, W. H., \& Anderson, E. Water quality, fishery, and biologic characteristics in a shallow, eutrophic lake with dense macrophyte populations. Lake and Reservoir Management, 8(2), pp.175-188. 1994

[9] Wallace, J. B., \& O'Hop, J. Life on a fast pad: waterlily leaf beetle impact on water lilies. Ecology, 66(5), pp. 1534-1544. 1985.

[10] Álvarez Bernal, D., Lastiri Hernández, M. A., Buelna Osben, H. R., Contreras Ramos, S. M., \& Mora, M. Vermicomposta como alternativa para el manejo del lirio acuático. Revista internacional de contaminación ambiental, 32(4), pp. 425-433. 2016.

[11] Roussel, D. K. V., Rámirez, I. J. D., \& Espinosa, E. E. Reivindicando las malezas: una oportunidad en el compostaje. Kuxulkab, 25(52), pp. 31-38. 2019.

[12] Prieto, L. C., Montaño, A. A., Parra, A., \& Puerto-Suárez, J. D. Evaluación Mecánica y Ambiental del Uso de Ceniza Volante con Activación Alcalina como Alternativa de Reemplazo Total del Cemento en la Elaboración de Tabletas Prefabricadas. Información tecnológica, 30(3), pp. 67-82. 2019.

[13] Hanafiah, H., Saloma, S., Yuwenka, D., \& Firdaus, M. E. The Effect of Water-Cement Ratio on Sulfate Resistance of Self-Compacting Concrete with Bagasse Ash. International Journal on Advanced Science, Engineering and Information Technology, 8(6), 2496-2503. 2018.

[14] Roz-Ud-Din Nassar, "Characteristics of Recycled Aggregate Concrete Produced with Crushed Stone Sand as Fine Aggregate," Civil Engineering and Architecture, Vol. 8, No. 4, pp. 632 - 640, 2020. DOI: 10.13189/cea.2020.080426.

[15] Suarez-Dominguez, E. J., Perez-Rivao, A., Sanchez-Medrano, M. T., Perez-Sanchez, J. F., \& Izquierdo-Kulich, E. Mesoscopic model for the surface fractal dimension estimation of solid-solid and gas-solid dispersed systems. Surfaces and Interfaces, 18, 100407. 2020.

[16] A. Martínez Loaiza, J. F. Pérez-Sánchez, E. J. Suárez-Domínguez, M. T. Sánchez-Medrano, V. M. García Izaguirre, A. Palacio-Pérez Morphological Evaluation of Surface Degradation and Mechanical Properties of Compressed-Earth Blocks (CEB). Civil Engineering and Architecture, 9(4), $992 \quad$ - $998 . \quad$ DOI: 10.13189/cea.2021.090403. 2021. 